\title{
O Início do Pensamento em Torno do Turismo de Base Comunitária: estudo de caso na comunidade de Galiléia, município de Caparaó, Minas Gerais, Brasil
}

The First Reflection about the Community Tourism: a case study research at community of Galiléia, municipality of Caparaó, Minas Gerais, Brazil

Marina Araújo ${ }^{1}$

\begin{abstract}
Resumo
A proposta de um trabalho com o turismo de base comunitária deve ser acompanhada de construções metodológicas que contribuam para o aumento da autonomia da população envolvida nos processos de decisão relativos ao turismo em seu território. Nesse sentido, esse artigo se propõe a apresentar os resultados da aplicação de uma metodologia construída para o trabalho de iniciação ao pensamento sobre o turismo de base comunitária na Comunidade de Galiléia, Município de Caparaó, Estado de Minas Gerais. A partir da adoção de métodos específicos das metodologias participativas no trabalho de planejamento turístico de base comunitária, foi possível aumentar o poder de decisão da comunidade em relação ao desenvolvimento do turismo em seu território.
\end{abstract}

Palavras-chave: participação comunitária; turismo de base comunitária; metodologias participativas.

\section{Abstract}

The Community Tourism proposal should be made with methodological constructs that contribute to increase the populations' autonomy in the decisions processes of tourism in its territory. So, this article presents the results of the methodology specially prepared for the Galiléia Community, situated at the municipality of Caparaó, Minas Gerais, where the researcher began to introduce the knowing about the Community Tourism. These methodologies are appropriates to the work with traditional communities that we want to implement the Community Tourism.

Keywords: community participation; community tourism; participatory methodologies.

\section{Introdução}

Evidencia-se, cada vez mais, na sociedade atual a importância de se incluir a população local na dinâmica turística, desde o seu planejamento até a gestão da atividade, como forma de se

\footnotetext{
${ }^{1}$ Bacharel em Turismo pela Universidade Federal de Minas Gerais. Servidora pública do Município de Itabira, MG, no Departamento de Turismo da Prefeitura Municipal. E-mail: amarinaaraujo@yahoo.com.br.
} 
alcançar o desenvolvimento sustentável e de minimizar os possíveis conflitos que a atividade turística possa ocasionar.

Dessa forma, acredita-se que o turismo de base comunitária, entendido como aquele que envolve a população local em todas as etapas dos projetos turísticos e a ela proporciona controle efetivo sobre sua gestão (MITRAUD, 2003), pode contribuir de forma positiva para a geração de mais benefícios para a população local e para a sua autonomia nos processos de decisão relativos ao turismo em seu território. A comunidade pode e deve decidir que tipo de turismo e, conseqüentemente, que tipo de mudanças e novas configurações territoriais está disposta a aceitar. Para tanto, é necessário também que a própria população esteja apta a fazer suas escolhas e saiba, consciente e criticamente, quais são seus impactos e implicações.

Acredita-se que o uso de ferramentas como as do Diagnóstico Rural Participativo - DRP (VERDEJO, 2006), do Planejamento Estratégico Participativo - PEP (DIESEL et al, 2004) e da Intervenção Participativa dos Atores - INPA (FURTADO; FURTADO, 2000), aliado ao planejamento turístico de base comunitária pode contribuir para a educação da população, de maneira geral, para a decisão acerca de seus problemas cotidianos; para o aumento da participação da população nas diferentes fases do mesmo; além de contribuir para o levantamento de potencialidades naturais, sociais, econômicas e culturais locais para a implantação do turismo em seu território. Considera-se que, dessa forma, o planejamento seria mais bem adaptado às condições sociais, econômicas, políticas e físicas de cada lugar, além de ser pautado no conhecimento crítico da realidade local e na participação efetiva de seus diversos atores.

Diante do exposto, questionou-se: é possível aplicar tais metodologias participativas no planejamento turístico em uma localidade onde o turismo não é concebido como uma alternativa econômica e social pela população, apesar de possuir potencial para o seu desenvolvimento? Que tipo de resultados em relação ao desenvolvimento do turismo nos territórios poderiam ser alcançados a partir da sua aplicação em uma dessas localidades?

Sendo assim, o objetivo desse artigo é apresentar os resultados da aplicação de uma metodologia elaborada especificamente para o trabalho de iniciação ao pensamento sobre o 
turismo de base comunitária na Comunidade de Galiléia, Município de Caparaó, Estado de Minas Gerais. Buscou-se, através dessa metodologia, estimular nos atores locais a construção de um pensamento crítico em relação ao desenvolvimento do turismo por meio do (re)conhecimento de seu território e sua cultura e da concepção de possíveis ações da comunidade para autogerir o turismo na Galiléia. Através do uso de ferramentas como as do DRP, do PEP e da INPA para o planejamento turístico de base comunitária, buscou-se uma forma de estimular a participação e o poder de decisão desses atores em relação à possível implantação do turismo na comunidade.

\section{Turismo Convencional X Turismo de Base Comunitária}

O turismo pode ser compreendido como um fenômeno social, cultural e espacial que, por seu tríplice aspecto em relação aos seus espaços - possui áreas de dispersão ou emissoras; áreas de deslocamento; e de atração ou receptoras (RODRIGUES, 1999) -, gera uma demanda por diversos bens e serviços nas localidades onde se desenvolve. Por esse motivo, tem se configurado, na atualidade, como uma importante atividade econômica capaz de fomentar diversos outros setores da economia, seja em âmbito local, regional, nacional ou mundial.

No entanto, o turismo envolve uma variedade de atores como, por exemplo, os moradores locais, setor empresarial e administração pública o que, por conseqüência, gera uma diversidade de expectativas em relação ao seu desenvolvimento. A capacidade de articulação entre esses atores e seus diferentes interesses contribui de forma positiva para o planejamento de um turismo mais responsável e consistente nas localidades. No entanto, o que se observa é que, ainda que haja um planejamento turístico prévio, a adoção de uma postura essencialmente econômica e comercial em relação ao turismo, por parte do poder público (responsável pelo planejamento turístico local e regional) e dos investidores tem promovido uma série de impactos negativos aos lugares e, principalmente, à sua população.

Assim, "até mesmo os efeitos positivos, nesse contexto, podem ser questionados" (OLIVEIRA, 2005, p.3), como pode ser observado no estudo de Botelho (2006). Segundo a autora, em função do turismo no Parque Estadual do Ibitipoca, o poder público local realizou 
diversos investimentos em educação, saúde e infra-estrutura básica no distrito de Ibitipoca, pertencente ao município de Lima Duarte. Entretanto, apesar desses pontos positivos em relação ao turismo, os benefícios gerados pela atividade não garantiram a inserção da população local na dinâmica turística em seu território. Nesse sentido, a comunidade, ao longo do tempo, assistiu a uma crescente concentração de rendimentos, advindos da atividade turística, nas mãos de uma minoria, moradores de outros municípios, que possuía recursos para investir em empreendimentos turísticos.

Nota-se, portanto, que o fomento do turismo nas localidades somente por seu viés econômico contribui para sua própria insustentabilidade econômica e social. Assim, ao mesmo tempo em que se deve reconhecer a capacidade da atividade turística estimular investimentos e fomentar a economia local, é preciso considerar que ela pode, em contrapartida, promover diversos impactos negativos, como a pressão inflacionária (alta geral nos preços de mercadorias e serviços básicos decorrentes do alto poder aquisitivo dos turistas que, na maioria das vezes, não é acompanhada pelo aumento do poder de compra da população local) e a especulação imobiliária, por exemplo.

Tais impactos negativos podem ter origem em cenários políticos, econômicos, sociais ou culturais frágeis que contribuem para o distanciamento e marginalização das comunidades em relação ao desenvolvimento do turismo em seu território. Assim, distante do processo de implantação da atividade turística, a população local pouco participa dos benefícios econômicos, sociais e culturais que a atividade proporciona. Na maioria das vezes os diversos aditamentos decorrentes da atividade turística, como a melhoria na infra-estrutura básica nas localidades, se direcionam a áreas próprias para o turista, e não exatamente para o atendimento das necessidades da população, como retratado por Oliveira (2005) em seu estudo de caso sobre o planejamento e gestão do turismo na Vila de Trindade, Paraty-RJ. Segundo ela, houve exclusão da população no processo de ocupação e desenvolvimento turístico na localidade, de forma que esta pouco participou dos benefícios advindos dessa atividade.

Nesse sentido, diversos estudos no campo do turismo (MENDONÇA, 2004; OLIVEIRA, 2005; BOTELHO, 2006; SANT'ANNA; OLIVEIRA; BERESTEIN, 2001) têm apontado a 
necessidade de efetivação da participação da população local em todas as etapas do planejamento turístico como uma forma de gerar mais benefícios para a mesma e de fomentar uma maior autonomia desses sujeitos nos processos de decisão relativos ao turismo.

Concorda-se com Murta (2000) quando afirma que há duas razões principais para que se leve em consideração os medos, desejos e necessidades da população local nos projetos turísticos: se o desenvolvimento do turismo não for compatível com os desejos e objetivos da comunidade, ou for dominado por interesses econômicos exclusivamente externos, conflitos e tensões podem resultar em declínio do turismo. Além disso, os residentes têm o direito de serem envolvidos na dinâmica de uma atividade que sempre traz custos e benefícios para sua comunidade.

A necessidade de participação popular no planejamento turístico se justifica, portanto, pelo fato de que nem sempre a população local é inserida na divisão dos benefícios advindos da atividade (sendo vítima e, ao mesmo tempo, agente de diversos impactos negativos) e pelo reconhecimento da contribuição que o autóctone, com seus costumes, modo de vida e conhecimento de seu território, suas potencialidades e fraquezas pode oferecer à gestão do turismo em sua localidade.

Esse é um dos princípios do turismo comunitário ou de base comunitária, definido pelo WWF-Internacional (2002, apud MENDONÇA, 2004, p.,4) como

aquele em que as sociedades locais possuem controle efetivo sobre seu desenvolvimento e gestão. E por meio do envolvimento participativo desde o início, projetos de turismo devem proporcionar a maior parte de seus benefícios para as comunidades locais.

A proposta do turismo de base comunitária surgiu de uma série de debates sobre o tipo de turismo desejável, principalmente, às comunidades tradicionais, indígenas, ribeirinhas e quilombolas, e sobre a necessidade de criação de novas formas de turismo, construídas em um modelo mais justo e equitativo, que levasse em consideração a sustentabilidade ambiental e que colocasse a população local no centro do planejamento, da implementação e do monitoramento das atividades turísticas. Esses debates alcançaram maior repercussão no Brasil durante o V Fórum Social Mundial de Porto Alegre, em 2005, e culminaram na 
elaboração da "Declaração de Porto Alegre: um outro turismo é possível" (NEUHAUS; SILVA, 2006). Nela o grupo de intervenções em turismo do Fórum reafirmou essa nova proposta de turismo, baseada na autogestão da atividade pelos atores locais, e se configurou como uma crítica ao desenvolvimento centralizador e excludente vigente na sociedade atual.

Baseado nos princípios da economia solidária, o turismo de base comunitária se configura, assim, como uma alternativa aos projetos turísticos tradicionais:

o turismo comunitário questiona o mito do turismo como gerador de emprego e renda e denuncia as políticas centradas na atração de investimentos que não levam em consideração a participação e o desenvolvimento das comunidades locais (TURISOL, 2008. p.3).

Assim, segundo a Rede Brasileira de Turismo Solidário e Comunitário-TURISOL (2008), o turismo de base comunitária tem como princípios:

- a participação dos atores locais desde o planejamento até a gestão do turismo em seu território, ou seja, a comunidade deve ser proprietária, gestora e empreendedora dos empreendimentos turísticos locais;

- a concepção do turismo como uma atividade complementar a outras atividades econômicas já praticadas na comunidade;

- a geração e distribuição de renda equitativa, praticando preços justos, satisfazendo a comunidade e turista, além de promover a distribuição de renda entre os moradores locais;

- a valorização cultural e a afirmação da identidade cultural local. As atividades são criadas para proporcionar intercâmbio cultural e aprendizagem ao visitante. Não se trata de apresentações folclóricas da cultura popular, mas de atividades que fazem parte do cotidiano que o turista vai experimentar;

- a concepção do modo de vida local como principal atração turística da comunidade;

- o entendimento de que a atividade turística só é viável quando construída sobre uma base associativa, ou seja, o sucesso individual está condicionado à sustentabilidade do ambiente que o cerca; 
- a relação de parceria e troca entre o turista e a comunidade. O turista é visto como um parceiro, não como um cliente;

- a conservação e sustentabilidade ambiental;

- a cooperação e parceria entre os diversos segmentos relacionados ao turismo de base comunitária;

- o trabalho com regras, normas e padrões estabelecidos entre a comunidade local em relação à gestão do turismo em seu território;

- o auxílio na luta pela posse da terra pela comunidade através do turismo de base comunitária.

Diversas experiências de turismo de base comunitária podem ser verificadas no nordeste do Brasil, onde, devido à tradicional política de atração de investimentos para o fomento do turismo de sol e praia, a maioria das comunidades que já faziam parte da rede de turismo nacional usaram o turismo comunitário como instrumento de defesa dos seus direitos à propriedade da terra, como ocorreu na Prainha do Canto Verde, em Beberibe, Estado do Ceará.

A mobilização dessa comunidade em torno de seus interesses comuns se iniciou na década de 70, quando um especulador, que se dizia dono de uma área de 749 ha. da localidade, pediu a desocupação desse território pelas famílias de pescadores que lá viviam. A resistência dos moradores à saída da comunidade foi fomentada, em um primeiro momento, pela articulação dos grupos da Igreja Católica e, posteriormente, pela criação da Associação dos Moradores da Prainha do Canto Verde, em 1989. Segundo Lindomar Fernandes (2006), coordenador da Cooperativa de Turismo e Artesanato da Prainha do Canto Verde, desde 1993 as lideranças comunitárias discutiam a possibilidade de se trabalhar com o turismo como uma alternativa de renda para as comunidades litorâneas. Foi a partir de então, com o apoio da ONG Instituto Terramar, que a comunidade começou a se articular para poder trabalhar com o turismo em seu território.

O primeiro passo dado pelos atores locais foi procurar conhecer a realidade do turismo em outras praias do Ceará, em especial, os benefícios e problemas decorrentes da atividade turística nessas localidades. Após diversas discussões acerca do tema, os moradores da 
Prainha do Canto verde decidiram que eles próprios seriam os gestores do turismo em seu território e, ao mesmo tempo, conservariam sua atividade econômica principal - a pesca - e as belezas naturais da região. Optaram, dessa forma, pelo turismo de base comunitária que é gerido, desde então, pela Cooperativa de Turismo e Artesanato da Prainha do Canto Verde. Dessa forma, a comunidade tem sido reconhecida como uma referência de sucesso em turismo de base comunitária tanto no Brasil como no exterior.

Diante do exposto, é possível afirmar que o turismo de base comunitária difere-se sobremaneira do turismo convencional: enquanto este se inspira no crescimento e no mercado e, assim, tem como principais objetivos o lucro e a produção, aquele configura-se como práticas solidárias e democráticas de trabalho e pauta-se na distribuição equitativa das riquezas geradas pelo desenvolvimento da atividade. Configura-se, assim, como uma forma de organização com base na propriedade e na autogestão dos recursos patrimoniais comunitários que, segundo Ramos (1997) são constituídos pelos conhecimentos, as práticas cotidianas, os instrumentos e as técnicas, a terra, a construção do território. São as expressões do modo de vida e da organização social, o conjunto de manifestações, representações e as múltiplas expressões do sujeito coletivo.

Nesse sentido, e tendo em vista a negligência com que esse patrimônio comunitário geralmente é tratado nos tradicionais planos turísticos, o turismo de base comunitária tem como princípio a conservação da biodiversidade e da diversidade cultural, ao dar voz e valorizar o modo de vida, tradições e pontos de vista da população local em relação ao turismo. Esses são os três princípios básicos do chamado Arranjo Socioprodutivo de Base Comunitária (SAMPAIO et al., 2006), dentro do qual se encontra o turismo de base comunitária.

Segundo esses autores, as experiências desse tipo de turismo se dão sob a perspectiva da socioeconomia das organizações - alicerçada na ecologia profunda, na economia social e no planejamento participativo -, na qual se privilegiam ações no âmbito de uma rede horizontal de cooperação. Ou seja, é um turismo baseado na interação da comunidade entre si, nos processos de planejamento e gestão do turismo, e desta com o turista, cuja motivação da visita também se difere da motivação do turista de massa. 
Nas palavras de Sampaio et al. (2006, p.6),

nessa perspectiva, o turismo de base comunitária é um divisor de águas. Ele se baseia na relação dialética entre turista e comunidade receptora, e não na sobreposição da comunidade ao turista. Turista e comunidade, ambos, são considerados agentes de ação sócio-econômico-ambiental que devem repensar as bases de um novo tipo de desenvolvimento, regulando padrões de consumo e estilos de vida, e de um conjunto de funções produtivas e socioecológicas, regulando a oferta de bens e serviços e seus impactos ambientais.

Assim, uma das estratégias para se alcançar, através do turismo de base comunitária, uma alternativa possível à sociedade de consumo que se quer menos homogeneizada e excludente, é o estímulo às comunidades a protagonizarem seus modos de vida próprios nos planos locais de desenvolvimento do turismo. Dessa forma, no turismo de base comunitária a participação da população local é premissa para assegurar a legitimidade, a representatividade e o sucesso nas ações dos planos turísticos. E, assim, na medida em que potencializa o grau de participação dos atores locais nas decisões sobre seu futuro e sua interação na construção de objetivos comuns, o planejamento turístico de base comunitária estimula, por conseqüência, maior envolvimento popular nas decisões políticas, sociais e econômicas de uma determinada comunidade (DIAS, 2003).

Dessa forma, é necessário pensar um planejamento turístico que tenha como base a participação comunitária em seus projetos e planos estratégicos. Os atores locais podem e devem decidir que tipo de turismo e, conseqüentemente, que tipo de mudanças e novas configurações territoriais estão dispostos a aceitar. E, para tanto, é preciso que a população esteja apta a fazer suas escolhas; que conheça, de forma crítica, os possíveis impactos e implicações decorrentes da atividade turística; e que esteja disposta a trabalhar de forma coletiva para o desenvolvimento do turismo em seu território.

Há necessidade, portanto, de uma intervenção que estimule nos sujeitos, de maneira geral, a reivindicação sobre o seu direito na participação dos benefícios advindos da atividade turística, sejam eles culturais, ambientais, econômicos ou sociais. Esta foi a proposta de intervenção realizada na Comunidade de Galiléia no ano de 2008: a de, por meio do uso de diferentes métodos das metodologias participativas para o desenvolvimento do turismo de 
base comunitária, estimular nos atores locais o conhecimento crítico de sua realidade cotidiana e sua problematização em relação ao turismo em seu território. As características e peculiaridades da comunidade de Galiléia serão descritas a seguir.

\section{A Comunidade de Galiléia, Caparaó, Minas Gerais}

A comunidade de Galiléia pertence ao município de Caparaó, estado de Minas Gerais, e localiza-se no entorno do Parque Nacional do Caparaó (ParNa do Caparaó), a aproximadamente $351 \mathrm{~km}$ de Belo Horizonte, na região da Zona da Mata mineira.

A região de Caparaó situa-se nas terras mais altas da porção sudeste do Brasil, na área montanhosa da Serra da Mantiqueira, que se estende até os limites dos estados de Minas Gerais, Espírito Santo e Rio de Janeiro. Situa-se, assim, na vertente oeste do maciço do Caparaó, cujo ponto culminante é o Pico da Bandeira (localizado no município de Alto Caparaó, Minas Gerais), o terceiro mais alto do Brasil, com 2890m de altitude (Instituto Brasileiro do Meio Ambiente e dos Recursos Naturais Renováveis - IBAMA, 2007). Está inserida em área de mata atlântica e possui clima tropical de altitude, ou seja, a topografia da região assume um importante papel na determinação das temperaturas anuais na localidade. Os principais cursos d'água de Caparaó são o Ribeirão da Fama e o Rio Caparaó, que corta a comunidade da Galiléia a oeste, e que pertencem à Bacia do Rio Itabapuana.

A história da região do Caparaó, assim como da comunidade de Galiléia, relaciona-se à plantação de café, cultivado desde o século XVIII quando, com o fim da mineração em Minas Gerais, o produto substituiu o ouro no processo de povoamento deste estado. A região da Zona da Mata mineira, nesta época, tornou-se agricultora, atraindo, a partir do final do século XIX, imigrantes italianos, espanhóis e portugueses (IBAMA, 2007).

Uma família de italianos, de sobrenome Brinati, foi responsável pelo início do povoamento da comunidade de Galiléia. Com ela, as famílias Nogueira e Xavier trabalhavam o plantio de 
lavouras brancas (milho, feijão, frutas, abóbora, dentre outras culturas) que, posteriormente, seria substituída, primeiro, por áreas de pastagem e, posteriormente, pelas lavouras de café 2 .

As famílias que foram se constituindo ao longo do tempo na Galiléia, segundo seus moradores, permaneceram na comunidade e começaram a ocupar, principalmente, a região da serra, que precisou ser desmatada para o plantio do café. Foram poucas as famílias de outras localidades que foram morar na área, de forma que no ano de 2008 , toda a comunidade ainda permanecia unida por laços familiares. Os córregos que cortam a Galiléia no sentido lesteoeste marcam espacialmente a distribuição dessas famílias na comunidade: o Córrego da Limeira ou Córrego dos Nogueiras, marca o território dos descendentes da família Nogueira; o Córrego Castorino, também conhecido como Córrego Xavier, dos descendentes da família Xavier, e a baixada, que é ocupada basicamente por pessoas da família Brinati.

A história da comunidade relaciona-se à união dessas famílias através da formação de grupos de reflexão da Igreja Católica, por volta de 1967. Os moradores da Galiléia se reuniam em uma antiga fazenda, cujos proprietários eram o Sr. Roberto Borges e D. Clarinda, devotos de Nossa Senhora Aparecida, para participar da catequese e celebrações. Como não havia um lugar grande o suficiente para acomodar todos os moradores, a primeira missa foi celebrada no curral dessa fazenda, no dia 07 de Julho de 1968, pelo Padre Geraldo Silva, que escolheu o nome da comunidade.

O ano de 1969 foi marcado pelo início da construção da capela de Nossa Senhora Aparecida e enquanto ela não ficava pronta, os cursos de base das pastorais, evangelização, plenárias e celebrações eram realizados na casa da venda, onde se localiza a Escola Municipal Sebastião Brinati. No início da década de 80 foram construídos uma nova Igreja (no lugar da capela), o salão comunitário e a quadra poliesportiva, através de mutirões e ajuda da prefeitura de Caparaó.

Nota-se, portanto, que a Igreja possuía um importante papel tanto na história da comunidade como na articulação de seus atores locais ao longo do tempo. Através da organização religiosa desses, eram realizados encontros das famílias, organização das pastorais, mutirões para a

\footnotetext{
${ }^{2}$ Informações obtidas através de entrevistas semi-estruturadas com os atores locais.
} 
realização de obras sociais na comunidade, encontros para conscientização da importância da preservação da água e das matas ciliares, construção de fossas nas casas, dentre outras ações.

A plantação de café também era uma cultura historicamente presente no cotidiano da comunidade e que se constituía como a principal atividade econômica da Galiléia, assim como em várias outras comunidades no entorno do município de Caparaó. De acordo com o Projeto Doces Matas (2001), a cafeicultura mobilizava de $70 \%$ a $95 \%$ da população economicamente ativa da zona rural do município de Caparaó. O café era cultivado na comunidade em monocultura e culturas de subsistência eram plantadas nas entrelinhas do café, sendo mais freqüentes o feijão e o milho, além de abóbora e mandioca, entre outras culturas.

O turismo surgiu como uma alternativa econômica para os municípios do entorno do ParNa do Caparaó a partir da década de 1960, quando essa Unidade de Conservação - UC, que abrange os estados de Minas Gerais e Espírito Santo, foi criada para proteger o entorno do Pico da Bandeira. Desenvolveu-se, portanto, de forma espontânea nas localidades: devido ao crescente fluxo de turistas para o parque, investiu-se na construção de pousadas, hotéis, lojas de artesanato e souvenires, restaurantes e agências de locação de veículos nas proximidades do mesmo.

Dessa forma, como os fluxos turísticos de Alto Caparaó e Caparaó existiam somente em função do Pico da Bandeira e do parque, principais atrativos turísticos da região, havia uma grande dependência dos empreendimentos turísticos em relação ao funcionamento da UC. Nesse sentido, seria preciso pensar um redirecionamento do fluxo turístico nas proximidades do parque, a fim de que houvesse maior valorização do seu entorno, composto, basicamente por comunidades rurais, e que os benefícios advindos do turismo não ficassem concentrados somente em um local.

Considerou-se, assim, que a comunidade de Galiléia poderia se constituir como uma das alternativas de visitação no entorno do ParNa do Caparaó, em Minas Gerais, uma vez que possuía potencial para o turismo rural que poderia ser implantado através de visitas às propriedades e vivência do processo de produção do café. E, ao mesmo tempo, nessa 
comunidade, o desenvolvimento do turismo de base comunitária seria facilitado por suas características sociais, culturais e ambientais. Como dito, na comunidade havia grande mobilização dos atores em torno da Igreja, um lugar de encontro para a prática religiosa e de sociabilidade entre os membros da comunidade.

As rezas, que aconteciam toda semana na Igreja, reuniam praticamente todos os moradores da comunidade nesse local, constituindo-se, assim, um lugar de encontro das diferentes famílias. Além disso, com o objetivo de refletir o Evangelho, as famílias foram organizadas pelos próprios moradores, em grupos que se reuniam a cada 15 dias em suas casas, para esse fim. Esses encontros, para além do seu aspecto religioso, eram importantes oportunidades para reflexão dos próprios problemas da comunidade. Quando havia uma família com dificuldades financeiras, por exemplo, esses grupos se articulavam e buscavam ajudá-la com cestas básicas.

Nota-se, portanto, que a Igreja possuía um importante papel na articulação desses atores locais e na manutenção de laços comuns que os uniam, seja por causa das rezas, da amizade ou devido ao seu espaço, utilizado para diversos fins. Apesar de não serem freqüentes, as reuniões e palestras dos agentes da Empresa de Assistência Técnica e Extensão Rural EMATER também aconteciam na Igreja, ou seja, por vezes, este local tornava-se lugar de encontro para se pensar também os modos de produção e as práticas cotidianas na cafeicultura.

Outro importante aspecto da mobilização coletiva na comunidade era a época de colheita do café, realizada em períodos distintos pelos agricultores da baixada e da serra, devido às diferenças no microclima dessas duas áreas. Os moradores da baixada colhiam-no antes dos da serra e, como o café é uma cultura que produz anualmente e devido à extensão das propriedades na Galiléia, eventualmente, precisavam de auxílio de mais pessoas para a colheita. Essa ajuda, por vezes, vinha de alguns agricultores da serra, que estavam no período de capina ou roça dos cafezais. O mesmo acontecia com os moradores da serra, quando chegava a sua época de colher café. 
Percebeu-se, assim, na comunidade, a existência de um patrimônio comunitário consolidado que contribuiu para a construção de uma sociedade democrática, socialmente justa e culturalmente conservacionista em relação ao turismo. Esse patrimônio comunitário é constituído pelos conhecimentos, as práticas cotidianas, os instrumentos e as técnicas, a terra, a constituição do território. É a expressão do modo de vida e da organização social, o conjunto de manifestações e representações e, enfim, as múltiplas expressões do sujeito coletivo.

Nesse sentido, acreditava-se que a proposta do turismo de base comunitária fosse a mais adequada à realidade da Galiléia, uma vez que, através do estímulo à autogestão do turismo pela população local, seria possível contribuir para que esse patrimônio comunitário e a identidade cultural local não fossem modificados ou extintos a partir do desenvolvimento da atividade.

Dessa forma, acreditava-se que o fato de os diversos atores da Galiléia, além de estarem unidos por relações sociais na comunidade, possuírem grau de parentesco entre si, contribuiria de forma positiva para a gestão desse patrimônio ao longo do tempo e, também, a conservação desse patrimônio a partir do contato com diferentes culturas que o turismo poderia proporcionar. Diante do exposto, e analisando a realidade da comunidade de Galiléia, afirmase que ela possuía um cenário sociocultural que tornavam viáveis a execução de processos participativos em relação ao turismo e, especialmente, a efetivação do planejamento do turismo de base comunitária, como pode ser comprovado no tópico "O início do pensamento em torno do turismo de base comunitária na Galiléia”.

\section{Metodologia}

O trabalho de iniciação ao pensamento em torno do turismo de base comunitária na comunidade de Galiléia fundamentou-se nos princípios dessa nova proposta de planejamento e gestão do turismo. As ações em campo basearam-se, especialmente, no conceito de turismo rural comunitário proposto pela Turisol (2008, p.5), uma vez que a comunidade possuía potencial para o mesmo: 
o turismo rural comunitário é composto por experiências planejadas e integradas de forma sustentável ao meio rural e desenvolvidas pelos atores locais organizados para o benefício da comunidade ${ }^{3}$.

Concretizou-se, sobretudo, através da utilização de metodologias participativas cujos métodos são flexíveis às condições culturais, sociais e econômicas locais e que são pautados na criatividade e inovação dos profissionais envolvidos no trabalho de planejamento participativo.

São diversas as metodologias de trabalho com a comunidade local que podem ser consideradas participativas, e todas elas oferecem contribuições ao turismo de base comunitária. No entanto, para se iniciar o processo de planejamento do turismo de base comunitária na comunidade de Galiléia, delimitaram-se três delas que serão descritas a seguir: o Diagnóstico Rural Participativo - DRP (VERDEJO, 2006), o Planejamento Estratégico Participativo - PEP (DIESEL et al., 2004) e a Intervenção Participativa dos Atores - INPA (FURTADO; FURTADO, 2000).

O DRP é concebido como um conjunto de ferramentas e técnicas que auxiliam as comunidades rurais a fazerem o diagnóstico de sua realidade cotidiana no trabalho com a terra para que, a partir daí, possam pensar diferentes ações no sentido de melhorar e corrigir possíveis falhas desse trabalho (VERDEJO, 2006). Seu objetivo principal é estimular a autodeterminação da comunidade pela participação e, assim, fomentar o desenvolvimento sustentável local. Nesse sentido, “embora originalmente tenham sido concebidas para zonas rurais, muitas das técnicas do DRP podem ser utilizadas igualmente em comunidades urbanas" (VERDEJO, 2006) e em diversas situações, como o planejamento turístico, por exemplo.

Ao contrário dos métodos convencionais de pesquisa, o DRP usa fontes diversas para assegurar uma coleta compreensível de informação, como a revisão de dados secundários; as fotografias aéreas e imagens de satélite; a observação direta de eventos, processos e das

\footnotetext{
3 "El turismo rural comunitario se compone de experiencias planificadas y integradas sosteniblemente al médio rural y desarrolladas por los pobladores locales organizados para beneficio de la comunidad" (tradução da autora).
} 
relações entre as pessoas; as entrevistas semi-estruturadas; os diagramas; os mapas e travessia; e os calendários de atividades.

A prática e a teoria do DRP variam segundo o contexto e a finalidade para os quais é usado. No entanto, têm algumas características comuns que podem ser assim enumeradas: é um processo de pesquisa e coleta de dados que pretende incluir as perspectivas de todos os grupos de interesse da comunidade; impulsiona uma mudança nos papéis tradicionais do pesquisador e dos pesquisados, uma vez que ambos participam da determinação de quais e como coletar os dados; reconhece o valor dos conhecimentos comunitários; e funciona como meio de comunicação entre aqueles que estão unidos por problemas comuns.

Assim, ao se analisar a contribuição que o DRP poderia oferecer ao turismo de base comunitária e ao trabalho de planejamento turístico na comunidade de Galiléia, não se pensou, propriamente, na solução de problemas em relação ao turismo (uma vez que a comunidade ainda não participava dessa dinâmica turística). Pensou-se na possibilidade de os atores, a partir de seus conhecimentos de senso comum acerca do turismo e da realidade do turismo convencional em outras localidades, conceberem formas críticas de lidar com o turismo em sua realidade cotidiana, construindo uma proposta de trabalho condizente com seu modo de vida, a fim de minimizar os efeitos negativos que a atividade pudesse causar na comunidade.

Considerou-se, ainda, que o DRP também poderia contribuir para o início do pensamento sobre o turismo de base comunitária na Galiléia ao oferecer subsídios para se pensar as limitações em relação à infra-estrutura básica da comunidade, o estado de seus recursos naturais e culturais e demais aspectos que são anteriores à implantação e desenvolvimento do turismo e, assim, para o levantamento de potencialidades e de possibilidades para a implantação do turismo na comunidade. Ao mesmo tempo, ao promover a análise da realidade local, a busca de soluções para os problemas e a ação coletiva na sua superação, o DRP se revelaria como um processo democrático de tomada de decisões que promoveria o reforço do poder da comunidade sobre seu território, aspectos que se almejava reafirmar ao longo do processo de planejamento do turismo de base comunitária na Galiléia. 
O Planejamento Estratégico Participativo é uma modalidade de planejamento participativo que foi protagonizada pela Secretaria de Desenvolvimento Rural do município de Santa Maria, Rio Grande do Sul, e que passou a fazer parte de seu programa de governo a partir de 2001. A metodologia, proposta por pesquisadores da Universidade Federal de Santa Maria, baseou-se no princípio Freireano de ação pedagógica, passando pelos três momentos de construção do conhecimento propostos pelo autor: problematização, ou conhecimento da realidade; tematização; e aplicação do conhecimento (DIESEL et al., 2004).

A especificidade do PEP, segundo os autores é a ênfase no processo educativo que permeia o planejamento, que se inspira nas iniciativas de pesquisa-ação ${ }^{4}$. Por isso, distingue-se das experiências de planejamento participativo que têm como fim maior a mobilização da população para resolução de problemas imediatos bem como das experiências com viés tecnocrático que resultam na elaboração de um plano de desenvolvimento formal. Propõe, assim, uma interação dialética entre o saber acadêmico e o conhecimento dos sujeitos do processo de planejamento através do tripé sensibilização-problematização-conscientização.

Considerou-se que, a partir da transposição da metodologia de PEP para a realidade do turismo de base comunitária, seria possível pensar coletivamente sobre o tipo de turismo e de turista que seriam desejáveis à Comunidade de Galiléia e, conseqüentemente, quais mudanças territoriais, sociais e culturais a comunidade estaria disposta a aceitar em decorrência do turismo. Através da problematização da realidade do turismo em outras localidades e da identificação do nível de conhecimento dos atores em relação à atividade e seus impactos, poderiam se conceber formas alternativas de organização espacial do turismo na Galiléia, de forma a proporcionar maiores benefícios sociais, econômicos e culturais à mesma.

A Intervenção Participativa dos Atores, por sua vez, configura-se como uma metodologia de capacitação para a atividade intervencionista no trabalho participativo com comunidades, desenvolvida para o Instituto Interamericano de Cooperação para a Agricultura - IICA por Furtado; Furtado (2000). O trabalho elaborado pelos autores fazia parte das atividades de capacitação do Projeto de Combate à Pobreza Rural, que atuava no nordeste do Brasil no final 
da década de 1990, e tinha como base a metodologia dialética da educação popular, a construção do conhecimento e adotava a concepção e os procedimentos da pesquisa-ação como instrumento de intervenção.

Segundo Furtado; Furtado (2000), os princípios do INPA podem ser aplicados em qualquer processo educativo participativo, servindo de referência teórico-prática para a atuação na sala de aula, reunião, palestras e até mesmo na convivência familiar. Partindo do princípio de que a maioria das pessoas que atuam em comunidades rurais trabalha na perspectiva de transmissão de conhecimento e, como tal, descontextualizada e unilateral, os autores defendem a necessidade de mudança de postura desse profissional: mais crítica, reflexiva, interativa e flexível nas suas ações.

Acreditava-se que a metodologia da INPA, ao refletir sobre a atuação do profissional em uma comunidade, também levaria à percepção da importância de uma postura adequada do planejador em relação à população local na concepção de projetos turísticos: ele deveria ser um estimulador, um facilitador no processo de reconhecimento da realidade, na sua análise e no planejamento das ações conjuntas na localidade. Dessa forma, os aspectos levantados por Furtado; Furtado (2000) deveriam ser observados durante todo o processo de planejamento e da autogestão do turismo de base comunitária na Galiléia, uma vez que a participação dos atores locais é um dos princípios fundamentais dessa proposta de trabalho com o turismo. É necessário ressaltar, ainda, que no trabalho com comunidades como a Galiléia, em que se pretendia iniciar um pensamento em torno do turismo, uma postura inadequada e impositiva do profissional em relação à população local poderia contribuir para se reforçar a idéia do turismo convencional nas localidades e, dessa forma, alcançaria pouca aceitação da proposta de turismo de base comunitária entre os atores.

Por fim, concebeu-se que o alinhamento de filosofias e métodos dessas três metodologias à proposta de turismo de base comunitária seria o elemento crucial para que se alcançassem mudanças fundamentais no modo de se conceber a relação entre a comunidade local e o desenvolvimento do turismo. Assim, buscou-se delinear uma proposta de intervenção com a

\footnotetext{
${ }^{4}$ A pesquisa-ação é uma ferramenta metodológica que supõe uma forma de ação planejada de caráter social, educacional, técnico e participativo, que nem sempre se encontra em propostas de pesquisas participantes
} 
comunidade capaz de fomentar a participação dos atores locais no planejamento e autogestão do turismo em seu território como forma de assegurar a legitimidade, a representatividade e o sucesso dessas ações. Através dessa intervenção, estimulou-se nos sujeitos o reconhecimento de si, de suas condições de vida e de sua realidade para melhor elaborar o planejamento de sua ação em seu território e, assim, agir de forma consciente e crítica em relação à possível implantação da atividade turística na localidade.

Assim, o trabalho na comunidade foi composto por cinco etapas: 1) preparação para as intervenções na comunidade; 2) (re)conhecimento da identidade local; 3) problematização do turismo em relação à realidade da comunidade; 4) conhecimento da proposta do turismo de base comunitária; e, por fim, 5) elaboração da "Carta da Galiléia para o turismo". Essas etapas, descritas a seguir, foram realizadas em dois trabalhos de campo: no primeiro deles, em maio de 2008, foi feita a preparação para as intervenções na comunidade e no segundo, em junho de 2008, realizou-se uma reunião, com duração de quatro horas, em que se efetivaram as outras quatro etapas do trabalho na Galiléia.

\subsection{A preparação para as intervenções na comunidade}

A etapa de preparação para as intervenções, realizada em maio de 2008, configurou-se como um primeiro contato entre a pesquisadora e a comunidade local. Utilizou-se o método de observação participante ${ }^{5}$ a fim de se conhecer as relações sociais dos atores entre si e a organização territorial e religiosa da comunidade (o papel da Igreja e das rezas nas relações comunitárias), aspectos que ajudaram a pesquisadora a entender a realidade de vida dos sujeitos com os quais iria trabalhar.

O método de entrevista semi-estruturada também foi utilizado nesta primeira etapa de trabalho. Através de visitas pessoais e de perguntas direcionadas a cinco pessoas-chaves da Galiléia, a pesquisadora pôde conhecer, em linhas gerais, a realidade cultural, social, econômica, política, territorial e ambiental da localidade para, posteriormente, definir suas estratégias de ação com a comunidade. 
Aliado ao uso da entrevista semi-estruturada foram utilizados os métodos "Mapa da Comunidade" (Anexo 01), com o objetivo de se conhecer a estrutura social da Galiléia, número de lares e o tipo de ocupação do espaço da mesma, e "Árvore Genealógica" das famílias fundadoras da comunidade (Anexo 02), uma vez que a maior parte dos atores era unida por laços familiares. Através da aplicação dessas duas ferramentas, foi possível perceber que as famílias da Galiléia, além de estarem unidas genealogicamente, concentravam-se em territórios específicos dentro do espaço da comunidade, devido à história de ocupação desse espaço, como foi afirmado no tópico “A comunidade de Galiléia”.

Nesta etapa da pesquisa também foi aplicado o método "Calendário Agrícola" (Anexo 03), com o objetivo de visualizar as épocas de muito trabalho na comunidade, suas principais atividades cotidianas e os ciclos agrícolas, para a definição da melhor data para a reunião com os atores locais e, ao mesmo tempo, se pensar em possibilidades para o trabalho com o turismo rural de base comunitária na Galiléia.

Assim, a partir do conhecimento da realidade e da ocupação social e espacial da comunidade foi possível identificar um líder que contribuiu para o levantamento de importantes aspectos para se pensar como seria a reunião com os atores locais, para o início do planejamento turístico comunitário na Galiléia. Através de uma reunião com esse informante definiu-se:

- Os participantes potenciais da reunião, com o cuidado de selecionar pessoas que representassem cada um dos grupos de interesse da comunidade;

- A melhor data para a realização da mesma, levando-se em consideração as temporadas de muito trabalho ou demanda de mão-de-obra e os ciclos agrícolas;

- O tempo de duração, respeitando as responsabilidades de trabalho e as atividades domésticas dos participantes;

- O local onde ocorreria a reunião. O critério mais importante de seleção deste lugar foi a sua acessibilidade física e social para a comunidade;

\footnotetext{
${ }^{5}$ A observação participante é obtida por meio do contato direto do pesquisador com o fenômeno observado, para recolher as ações dos atores em seu contexto natural, a partir de sua perspectiva e seus pontos de vista (CHIZZOTTI, 2001).
} 
- A forma de se convidar a comunidade para a reunião. Tal convite foi feito através de uma carta entregue a um dos atores locais, que ficou responsável por repassá-la às famílias que participariam da mesma em uma das celebrações na Igreja ${ }^{6}$.

Com isso, a pesquisadora obteve informações suficientes para definir suas estratégias de trabalho ao longo da reunião, as técnicas e tipos de intervenções que seriam realizadas com a comunidade. Elaborou-se, então, ao final dessa etapa de preparação, um plano de ação para a reunião agendada com a comunidade, com as formas de execução das outras quatro etapas do planejamento turístico de base comunitária propostas neste trabalho, como se observa a seguir:

Data da reunião: 07/06/08 (sábado)

Horário: de 14:00 às 18:00h.

Local: Salão da Igreja Nossa Senhora Aparecida

Participantes: Luciana e Gladistone, Silvana, Esmelinda, Teresinha e Simião, Sebastião, Valquer, Lúcia, Cristina e Alessandro e Aparecida.

- 14:00 às 14:10h - Exposição oral

Conteúdo: Apresentação da pesquisadora. Agradecimento pela disponibilidade da comunidade em contribuir com o trabalho. Apresentação da proposta e objetivos do trabalho.

Objetivos: Reforçar a importância da participação da comunidade nesse trabalho. Esclarecer aos participantes quais os objetivos do mesmo.

Procedimentos: Apresentar, de forma clara e simples, a proposta de trabalho na Galiléia: iniciar o pensamento acerca do turismo na comunidade (não trabalhar, nesse primeiro momento, o conceito de turismo de base comunitária).

Materiais:

- 14:10 às 14:30h - Dinâmica "Cada um com o seu balão"

Conteúdo: Trabalho em equipe, cooperação mútua.

Objetivos: Promover a familiarização dos participantes. Sensibilizá-los sobre a importância do trabalho em equipe e da participação de cada um ao longo da reunião.

Procedimentos: Os participantes foram posicionados em círculo e cada um recebeu três balões. Pediu-se que todos juntos jogassem seus balões para o alto e mantivessem-nos no ar, sem que nenhum deles tocasse o chão. Terminada a dinâmica, abriu-se espaço para relatos e

\footnotetext{
${ }^{6}$ No segundo trabalho de campo, esse convite foi reforçado através de visitas pessoais aos participantes na véspera da data marcada para a reunião.
} 
percepções acerca da mesma em relação à vida na comunidade. Estimulou-se, então, a visão da interligação e interdependência das ações comunitárias pelo grupo.

Materiais: balões coloridos

- 14:30 às 15:40h - Etapa 2: (re)conhecimento da identidade cultural local. Dinâmica "Painéis coletivos: pensando o passado, presente e futuro da comunidade"

Conteúdo: Descrição das características físicas, sociais, culturais, econômicas e ambientais da comunidade. Visualização das particularidades desse território. Reflexão sobre a identidade cultural da comunidade. Visualização do passado, presente e futuro desejado para a comunidade.

Objetivos: (Re)conhecimento do território e da identidade cultural local. Caracterização da comunidade a partir do ponto de vista dos atores locais.

Procedimentos: Os participantes foram divididos em três grupos que representaram, através de imagens recortadas de revistas, o passado, presente e o futuro da comunidade. Estimulouse os grupos a falarem como eles viam a comunidade, quais eram suas características singulares. Em seguida, os atores locais determinaram qual era a identidade cultural local e fizeram uma reflexão sobre o futuro desejado para a comunidade. Finalizou-se com a pergunta: o turismo pode fazer parte do futuro da comunidade?

Materiais: cartolinas, cola, tesouras, lápis, canetas coloridas, borrachas, revistas.

- 15:40 às 16:00h - Etapa 3: problematização do turismo em relação à realidade da comunidade. Dinâmica "Papel amassado"

Conteúdo: Impactos negativos da atividade turística. Possibilidade de minimização desses impactos e aumento dos benefícios da atividade turística através da participação, cooperação e articulação da comunidade no planejamento e gestão do turismo local.

Objetivos: Refletir sobre as possíveis mudanças que o turismo acarreta nas localidades. Reforçar a importância da articulação da comunidade para a minimização dos impactos do turismo em uma localidade.

Procedimentos: Cada participante recebeu uma folha de papel sulfite e outra de papel cartão. Pediu-se que eles amassassem ambas as folhas e, posteriormente, que tentassem desamassálas. O papel cartão tem maior resistência que o outro porque suas fibras estão mais unidas e, dessa forma, é mais difícil quebrá-las. Propôs-se, então, uma reflexão sobre as modificações que o turismo poderia causar em uma localidade e reforçou-se a importância da articulação da comunidade para a minimização dos impactos do turismo na mesma.

Materiais: papel sulfite e papel cartão

- 16:00 às 16:40h - Etapa 3: problematização do turismo em relação à realidade da comunidade. Discussão em grupos

Conteúdo: Possibilidades para o desenvolvimento do turismo.

Objetivos: Saber se a comunidade estaria disposta ou não a trabalhar com o turismo em seu território. 
Procedimentos: Os mesmos grupos divididos para a dinâmica "Painéis Coletivos" foram estimulados a refletir sobre as possibilidades de o turismo fazer parte do futuro da comunidade. Cada um deles apresentou e discutiu com os demais grupos sobre o tema.

Materiais:

- $16: 40$ às $17: 00 \mathrm{~h}-$ Intervalo/lanche

- 17:00 às 17:20h - Etapa 4: conhecimento da proposta do turismo de base comunitária. Exposição oral e visual

Conteúdo: Conceito, características e princípios do turismo de base comunitária.

Objetivos: Refletir sobre a possibilidade de se trabalhar o turismo de base comunitária na comunidade de Galiléia.

Procedimentos: Apresentou-se, de forma clara e simples, o conteúdo proposto.

Materiais: cartazes e fita adesiva.

- 17:20 às 17:50h - Etapa 5: elaboração da "Carta da Galiléia para o turismo". Exposição oral e visual

Conteúdo: Pensar as ações necessárias e as condições dos atores para que o turismo seja implantado na comunidade.

Objetivos: Elaboração da Carta da Galiléia para o turismo.

Procedimentos: Registrou-se os aspectos mencionados pelos participantes em relação às condições e necessidades da comunidade em tarjetas, que foram afixadas em local visível para todos.

Materiais: tarjetas, pincéis, fita adesiva.

- $17: 50$ às 18:00h - Exposição oral

Conteúdo: Agradecimento à comunidade pelas contribuições ao trabalho.

Objetivos: Reforçar as contribuições oferecidas pelos atores durante toda a reunião.

\subsection{O (re)conhecimento da identidade cultural local}

Nessa etapa de trabalho foi estimulada nos atores uma reflexão sobre o passado, presente e futuro desejado pela comunidade, na tentativa de se identificarem as características peculiares da mesma e os desejos comuns dos atores locais, dentre os quais poderia estar o turismo. Procurou-se, então, através da dinâmica "Painéis Coletivos", fazer um reconhecimento das características culturais, territoriais, econômicas, ambientais e sociais, passadas e presentes, da comunidade. Assim, seria possível identificar como a população local concebia sua comunidade e qual era a sua identidade cultural. Ao mesmo tempo, ao se pensar no futuro da comunidade e nos desejos comuns dos atores locais em relação a ele, estimulou-se os 
participantes a pensarem na possibilidade do turismo fazer parte desse futuro, na tentativa de iniciar nos atores o pensamento em torno do turismo.

\subsection{A problematização do turismo em relação à realidade da comunidade}

Iniciado o pensamento sobre a possível implantação do turismo na Galiléia, os atores locais foram levados a refletir sobre como esta atividade poderia fazer parte do futuro da comunidade, através da problematização do turismo em relação à realidade de vida de seus habitantes. Para tanto, foi feita uma discussão em grupo sobre as possibilidades para que o turismo pudesse se inserir nessa realidade local e, dessa forma, os participantes expuseram o tipo de turista e de turismo que eram desejáveis à comunidade. Naturalmente, surgiram diversas condições para que o turismo se desenvolvesse na Galiléia, além de várias restrições às mudanças e temor aos impactos negativos que a comunidade poderia sofrer em decorrência dessa nova atividade.

Através da dinâmica "Papel Amassado" procurou-se evidenciar a necessidade de articulação doa autóctones na gestão do turismo como uma forma de minimizar os possíveis impactos negativos que a atividade turística pudesse ocasionar em seu território.

\subsection{O conhecimento da proposta do turismo de base comunitária}

Foram diversas as condições colocadas à implantação do turismo na Galiléia e várias delas correspondiam aos princípios do turismo de base comunitária. Apresentou-se, então, essa nova proposta de planejamento e gestão do turismo aos atores locais através da exposição de aspectos teóricos e relatos de experiências de outras comunidades.

\subsection{A elaboração da "Carta da Galiléia para o turismo"}

O objetivo dessa última etapa foi pensar, conjuntamente, as ações necessárias e as condições dos atores para que o turismo fosse implantado na comunidade. Nesse sentido, os participantes, organizando todas as reflexões feitas ao longo da reunião, registraram essas condições e necessidades em tarjetas, que foram afixadas na parede para que ficassem visíveis a todos. Assim, construiu-se a "Carta da Galiléia para o turismo", documento final do processo participativo na comunidade que contém os pontos de vista, anseios e expectativas 
dos atores locais em relação ao turismo, e que será apresentada no próximo tópico, juntamente com os demais resultados do trabalho na comunidade de Galiléia.

\section{O Início do Pensamento em Torno do Turismo de Base Comunitária na Galiléia}

As descrições e análises que se seguem foram baseadas nos resultados do processo inicial de problematização do turismo de base comunitária na comunidade de Galiléia. A partir da primeira etapa da pesquisa, de preparação para as intervenções na Galiléia, foi possível perceber que a Igreja era o elemento central na vida social e religiosa da comunidade. Sua própria história, contada pelos moradores locais, era lembrada a partir do início dos grupos de reflexão, em 1967, e, assim, do começo da organização religiosa da comunidade. Internamente, a Igreja na Galiléia organizava-se através das pastorais da catequese, dízimo, liturgia, Legião de Maria e dos grupos de reflexão, de forma que todas as famílias da comunidade se envolviam e possuíam responsabilidades na manutenção da organização religiosa da Galiléia.

Observou-se, ainda, que a participação na Igreja e os laços familiares genealógicos que uniam as famílias da Galiléia configuravam a base da relação comunitária fraterna presente na comunidade. Ao mesmo tempo, a cultura do café promovia um tipo de relação social entre seus habitantes denominada relação associativa (WEBER, 1994). Segundo o autor, nesse tipo de relação há um ajuste ou uma união de interesses racionalmente motivados, com referência a valores ou fins e, em relação à Galiléia, ela existe devido aos interesses comuns em torno da produção do café.

Assim, diante das informações coletadas no primeiro trabalho de campo, foi possível perceber que a comunidade de Galiléia possuía um cenário cultural, social e econômico propício à construção de uma proposta de turismo de base comunitária. A gestão do patrimônio comunitário, especialmente a organização religiosa, a solidariedade, a união dos atores por laços familiares e a sua organização em torno do café, poderia contribuir de forma positiva para que a comunidade tivesse consciência de sua trajetória histórica e de suas potencialidades 
e, assim, soubesse realizar escolhas com autonomia e desenvolver ações para concretizar essas escolhas.

O segundo trabalho de campo, constituído pela reunião com a comunidade, iniciou-se com a dinâmica "cada um com seu balão", que instigou nos atores reflexões sobre a importância do trabalho em equipe e da colaboração de todos na solução de problemas comuns. Através da reflexão sobre a atividade, os participantes relataram que os balões poderiam representar diversos aspectos da vida na Galiléia, como as celebrações, a catequese, o plantio e a colheita do café, a vida em família, dentre outros.

Vivê-los significaria se deparar com diversas dificuldades, que seriam mais facilmente superadas se houvesse união e cooperação mútua com as demais pessoas da comunidade. Com essa dinâmica iniciou-se a reflexão sobre o nível de articulação da comunidade em torno de seus interesses comuns, e o que se percebeu é que existia na Galiléia grande mobilização coletiva em torno de vários aspectos da vida cotidiana local.

Tais resultados reforçaram a idéia de que a população estaria cultural e socialmente preparada para trabalhar o turismo de base comunitária na Galiléia, através de parcerias entre si e da participação de todos na autogestão do turismo. Ao mesmo tempo, devido a essa mobilização coletiva, percebeu-se que o trabalho da pesquisadora durante a reunião seria apenas de mediar a construção do conhecimento sobre o turismo na comunidade, uma vez que a discussão sobre desejos e problemas comuns já acontecia na localidade. Bastaria então, estimular a problematização do turismo para que outros temas geradores pudessem surgir na reunião com os atores locais e, assim, para que se pudessem pensar alternativas para a implantação do turismo naquele território.

Esse foi o propósito da aplicação da dinâmica "painéis coletivos", através da qual foi estimulada nos participantes uma reflexão sobre o passado, presente e futuro desejado pela comunidade, na tentativa de identificar as características peculiares da mesma e os desejos comuns dos atores locais, dentre os quais poderia estar o turismo. Pediu-se aos participantes, divididos em três grupos, que representassem esses momentos da vida da comunidade em cartazes (com imagens, desenhos ou palavras) e que, posteriormente, apresentassem a todos o 
conteúdo dos mesmos. Solicitou-se, ainda, que os demais grupos fizessem as intervenções que julgassem necessárias ao final de cada apresentação, para complementar, validar ou questionar as reflexões apresentadas.

Segundo os moradores da Galiléia, a base da sua comunidade era a família. No passado, a localidade era composta por famílias grandes, que trabalhavam, basicamente, com o plantio de lavoura branca (quase todos os tipos de cultura, exceto o café), de frutas e com a criação de galinhas e porcos. Tratava-se de uma terra nova, com muitas áreas de mata que precisaram ser desmatadas para que se pudesse plantar. Havia, então, ricas reservas de fauna e flora que não foram preservadas devido à falta de consciência dos antigos moradores da comunidade. Esses não se preocupavam em preservar os recursos naturais porque não tinham conhecimento dos problemas que essa degradação poderia causar no futuro.

Todos os moradores da comunidade de Galiléia eram muito centrados no trabalho e tinham poucos momentos de confraternização entre si e de lazer. No entanto, as famílias se reuniam, periodicamente, para as rezas e celebrações.

Assim, a partir da primeira reflexão dos atores sobre o passado da comunidade, percebeu-se que as relações familiares e religiosas eram os principais elementos caracterizadores da mesma. A solidariedade e a relação comunitária da Galiléia eram, portanto, heranças culturais mantidas ao longo do tempo pelos atores locais, que ainda estavam presentes na realidade da comunidade.

A reflexão sobre a preocupação dos antigos moradores em desmatar para plantar revelou uma consciência dos atores participantes da reunião sobre a riqueza de seus recursos naturais e a necessidade de preservá-los. Ao mesmo tempo, demonstrou a preocupação dos mesmos em planejar bem suas ações no presente visando um futuro sustentável para a comunidade.

A representação do presente da Galiléia também se baseou nas relações familiares e religiosas da comunidade: uma imagem de Nossa Senhora Aparecida selecionada pelos participantes mostrou que a comunidade sempre esteve voltada para Maria, mãe de Jesus, e uma figura de gansos voando representou a união das famílias. Um dos participantes explicou que esses pássaros voam juntos e sempre na mesma direção. Quando um deles se cansa, ele se afasta e 
cede seu lugar a outro ganso, até se recuperar e retomar seu lugar. Assim também acontecia na Galiléia: quando uma pessoa precisava de auxílio (em diversos aspectos), a comunidade se mobilizava para prestar sua solidariedade a ela. Além disso, periodicamente, a coordenação dos grupos da Igreja precisava ser trocada, assim como fazem os gansos durante seus longos vôos, nos quais os pássaros que voam mais à frente cansam-se mais rápido que os demais e precisam ser substituídos.

Percebeu-se, então, que a Galiléia era uma comunidade articulada cultural e socialmente através da Igreja e de interesses comuns de sua população. A comparação do vôo dos gansos com a vida em comunidade revelou uma consciência dos atores locais para a necessidade de participação e ajuda mútua em diferentes aspectos de sua vida cotidiana e, ao mesmo tempo, de união de todos para alcançarem objetivos comuns.

A partir da visão dos atores locais sobre as características da comunidade, perguntou-se qual seria a identidade cultural local. Através do exemplo do documento de identidade de uma pessoa que, além do fenótipo (cor dos olhos, do cabelo, da pele), identifica o sujeito por sua data e local de nascimento, nome, filiação, dentre outros aspectos, pediu-se que os atores pensassem sobre a identidade da comunidade.

Segundo eles, a identidade é uma característica que vem do passado, se reflete no presente e que permanecerá no futuro da comunidade. Nesse sentido, a identidade da Galiléia era a família; a própria comunidade era uma grande família. Quando havia um problema na localidade, todos tentavam superá-lo juntos e, dessa forma, as pessoas cuidavam umas das outras, concretizando entre si, cotidianamente, o próprio conceito da palavra comunidade viver em comunhão. E essa unidade, segundo os atores locais, vinha da Eucaristia, da Igreja.

O principal aspecto mencionado pelos atores locais em sua reflexão sobre o futuro desejado para a comunidade foi a diversificação da produção na Galiléia, como uma forma de aumentar a renda da comunidade e, ao mesmo tempo, garantir uma vida com qualidade para a população. No futuro, esperavam poder explorar mais os recursos naturais da região com responsabilidade; produzir e vender artesanatos; trabalhar com a piscicultura, como forma de reconstituir a fauna 
local; continuar cuidando dos remanescentes de mata e das matas ciliares e, por fim, levar pessoas de fora para conhecerem a realidade da comunidade e a região da Galiléia.

Diante do exposto, perguntou-se aos participantes sobre a possibilidade do turismo ser uma realidade futura na comunidade. A resposta imediata dos atores locais à questão não foi um sim, nem um não, mas uma reflexão crítica sobre a realidade do turismo na região do ParNa do Caparaó.

Quando a portaria do parque foi aberta, os moradores de Minas Gerais e do Espírito Santo pensaram que iam obter grandes rendimentos através do turismo, o que, de fato, não aconteceu. Nessas localidades, tudo passou a girar em torno do turismo, todos os investimentos das pessoas foram feitos em pousadas, hotéis e restaurantes, o que não seria adequado à realidade da Galiléia.

Segundo os atores locais, se o turismo fizesse parte do futuro da comunidade, não poderia acontecer como em Caparaó, mas ele deveria ser concebido como uma atividade complementar à produção de café, como foi mostrado no cartaz de futuro desejado. Implicaria, assim, um posicionamento crítico em relação à sua implantação, sem se sonhar com um expressivo aumento da renda local, uma vez que isso nem sempre acontece, e sem se investir demasiadamente nessa atividade.

O turismo deveria, então, se associar, de forma harmônica, à vida cotidiana da comunidade, sem provocar mudanças bruscas em sua realidade econômica, social e cultural. Ao mesmo tempo, para que o turismo acontecesse na comunidade, seria necessário haver uma referência de demanda para a mesma. Nesse sentido, a proposta do Caminho da Luz ${ }^{7}$ passar pela comunidade, caso se tornasse uma realidade, poderia abrir caminhos para a implantação do turismo na Galiléia e, dessa forma, incentivar o trabalho com o mesmo na região.

Percebendo-se esse posicionamento crítico dos atores locais em relação à implantação e alguns impactos do turismo, como a dependência econômica dos moradores de Caparaó, por exemplo,

\footnotetext{
${ }^{7}$ O Caminho da Luz é um caminho de peregrinação religiosa, ecológica e histórica, de $195 \mathrm{~km}$, que tem início no município de Tombos, Minas Gerais, e fim no Pico da Bandeira. É administrado pela Associação Brasileira dos Amigos do Caminho da Luz - ABRALUZ, que cuida da sinalização e organização do mesmo.
} 
procurou-se trabalhar, através da dinâmica "Papel Amassado", a necessidade de articulação dos autóctones na gestão do turismo como uma forma de minimizar esses impactos.

As folhas de papel sulfite e papel cartão representaram a comunidade e o ato de amassá-los, as mudanças e diversos impactos que o turismo poderia causar às localidades. Depois de amassados, os papéis, por mais que se tentasse recompô-los, não voltariam a ser como eram antes. No entanto, através da vivência da atividade, os participantes perceberam que, ao mesmo tempo em que era mais difícil amassar o papel cartão, as marcas deixadas no mesmo eram menores.

Refletiu-se, assim, sobre a união da comunidade frente à implantação do turismo em seu território: assim como o papel cartão é constituído por maior quantidade de fibras unidas (por isso é mais difícil quebrá-las), quanto mais unida e articulada fosse uma comunidade na defesa de seus desejos comuns, menos impactos e modificações na mesma o turismo poderia causar. Portanto, quanto maior fosse a união dos autóctones, quanto mais claro estivesse para eles o tipo de turismo desejado na comunidade e as condições para que esse fizesse parte da realidade local, menos marcas essa atividade poderia deixar na mesma, uma vez que haveria um efetivo controle da comunidade em relação ao seu desenvolvimento.

Seguiu-se a essa reflexão coletiva a problematização do turismo em relação à realidade da comunidade. Propôs-se a reunião dos mesmos grupos que trabalharam na confecção dos cartazes para discutirem sobre o que pensavam sobre o turismo na Galiléia. Depois da reflexão, os grupos deveriam apresentar seus pontos de vista em relação à implantação do turismo na comunidade e, assim, iniciar um debate sobre o tema.

Segundo os moradores locais, a comunidade tinha capacidade de receber turistas, no entanto, ela precisaria se preparar para tanto. Seria necessário tempo para se pensar o turismo em seu território, se adaptar e para planejar melhor suas ações para a implantação da atividade na dinâmica local. Ao mesmo tempo, seria necessário que toda a população estivesse envolvida nesse planejamento, a fim de se organizarem e tornarem concretas as propostas em relação ao turismo, para que este não se configurasse somente como um sonho de grandes rendimentos, como aconteceu nos municípios do entorno do ParNa do Caparaó. 
Duas necessidades apontadas pelos participantes para que o turismo fizesse parte da realidade local foram a de se realizar um levantamento da possível demanda turística para a Galiléia e dos seus atrativos e de se fazer um estudo dos benefícios e impactos negativos que a atividade poderia causar à comunidade, com o objetivo de melhor direcionar suas ações em seu território. Consideraram que os viajantes do Caminho da Luz eram visitantes potenciais da comunidade: passando pela estrada que corta a localidade, poderiam parar em algumas propriedades, vivenciar a colheita e secagem do café, a produção de queijo, rapadura e defumados. Esses poderiam ser, portanto, os atrativos da comunidade, uma vez que as pessoas de fora, principalmente as que residem em centros urbanos, não conhecem e se interessam em saber como é o processo produtivo nas propriedades.

Assim, a partir das falas dos participantes durante a reunião, é possível afirmar que o turismo poderia fazer parte de uma futura realidade local, desde que não impusesse notáveis mudanças territoriais, culturais e sociais à comunidade de Galiléia. Dessa forma, o tipo de turismo e de turista desejados pelos atores locais não se enquadravam nos moldes do turismo convencional, o que pode ser confirmado pela afirmação dos mesmos sobre a necessidade de se investir na qualidade dos visitantes recebidos, e não na sua quantidade.

Nesse sentido, percebeu-se que os autóctones possuíam um posicionamento crítico em relação à racionalidade estritamente econômica vigente na sociedade atual e, dessa forma, propuseram um desenvolvimento alternativo ao turismo em seu território. A partir dessa postura dos autóctones, acredita-se que a inserção da comunidade na dinâmica mercadológica do turismo se daria de forma mais crítica e contextualizada à sua realidade de vida, sem se recorrer à importação de modelos de desenvolvimento turístico de outras localidades.

Diante do exposto, ficou evidente a capacidade de articulação da comunidade na defesa de seus desejos comuns e valores comunitários e, portanto, sua capacidade de autogestão do turismo em seu território, proposta central do turismo de base comunitária. Nesse sentido, após as reflexões feitas pela comunidade sobre si e sobre a realidade do turismo, julgou-se pertinente apresentar aos participantes da reunião o conceito e os princípios dessa nova proposta de planejamento e gestão do turismo. A intenção, nesse momento da reunião, foi de oferecer subsídios para a elaboração da "Carta da Galiléia para o turismo" através da 
confirmação da necessidade da autogestão da atividade pela população local e do estabelecimento de limites para o seu desenvolvimento na comunidade.

A apresentação da pesquisadora ocorreu com poucas intervenções dos participantes. Alguns deles comentavam entre si que certos princípios apresentados correspondiam, exatamente, ao que tinham exposto anteriormente, durante a etapa de problematização do turismo. Se, antes, suas falas poderiam desanimar a pesquisadora em relação à possível implantação do turismo na comunidade, durante a apresentação da mesma, ficou nítido a todos que se falava, ao longo de toda a reunião, de uma mesma proposta de turismo que se confirmou, naquele momento, tanto viável como necessária à comunidade de Galiléia.

Por fim, com base na apresentação da proposta do turismo de base comunitária e todas as reflexões feitas ao longo da reunião, propôs-se a elaboração da "Carta da Galiléia para o turismo", que deveria conter os pontos de vista, anseios e expectativas dos atores locais em relação ao turismo. As falas dos participantes foram registradas em tarjetas e afixadas na parede, de forma a ficarem visíveis a todos. Este foi, portanto, o resultado final do trabalho participativo na comunidade, concretizado através do registro do pensamento dos atores locais acerca do turismo de base comunitária na Galiléia na forma de uma correspondência endereçada a todos os componentes da cadeia produtiva do turismo.

\subsection{A "Carta da Galiléia para o turismo"}

Caparaó, 7 de junho de 2008.

Prezados turistas, turismólogos, ONGs, gestores, entidades e órgãos públicos que atuam no campo do turismo,

Sabemos que a implantação do turismo em uma localidade, assim como qualquer outra atividade econômica, exige tempo e uma preparação dos moradores que se propõem a receber visitantes em seu território. Nesse sentido, nós, da comunidade de Galiléia, entendemos como uma de nossas principais necessidades a realização de uma consultoria que seja capaz de verificar as possibilidades e potencialidades de nossa comunidade para o turismo. 
Acreditamos que esse estudo para a implantação do turismo deve contemplar, necessariamente, o conhecimento de nossos atrativos naturais e culturais, as necessidades de todos os moradores da Galiléia e os possíveis impactos que a atividade poderia causar em nosso território. É preciso, então, planejar quando e como o turismo irá acontecer na Galiléia, tendo em vista, dentre outras restrições, a conciliação desta atividade com a época de colheita do café, período em que todos trabalham muito na comunidade. Dessa forma, a oferta turística da Galiléia (entendemos que são os lugares que os turistas vão visitar, onde ficarão hospedados, aonde vão se alimentar e o tipo de refeições a serem oferecidas a eles) deve ser adequada à nossa realidade de vida, ou seja, essa oferta turística não pode custar muito dinheiro para investir e nem modificar nosso modo de vida.

Nesse contexto, é necessário afirmar que nossa comunidade não está disposta a abandonar a produção de café, enquanto principal atividade econômica de todas as famílias, para trabalhar apenas com o turismo. Esta seria, portanto, uma atividade complementar à existente na comunidade e, como dito, é necessário se planejar em que épocas ela irá acontecer na Galiléia, para que não modifique nossa dinâmica cotidiana de vida.

Nem sempre a comunidade estará disposta ou preparada para receber visitantes. Nesse sentido, uma das condições para que o turismo aconteça aqui é que os turistas agendem, com antecedência, sua visita à Galiléia, para que possamos nos programar para recebê-los e de forma que nossas tarefas do dia-a-dia não sejam comprometidas.

Acreditamos que a simples presença de pessoas de fora da comunidade é suficiente para modificar nossa dinâmica cotidiana. Dessa forma, esperamos que os visitantes queiram, sobretudo, viver nossa cultura, respeitando nosso modo de vida e adaptando-se a ele, contribuindo para a preservação do ambiente natural e cultural local e, principalmente, respeitando o ambiente familiar que caracteriza a Galiléia.

Por fim, entendemos que, para que todas as condições e necessidades expostas ao longo desta carta sejam satisfeitas, é preciso que haja uma organização interna da comunidade através de um conselho. A criação desse asseguraria uma melhor distribuição dos benefícios sociais e 
econômicos do turismo, além de trabalhar para o bem-estar de todos e na defesa de nossos interesses dos atores locais em relação à atividade.

Estas são as principais necessidades e condições que colocamos ao turismo e a quem com ele se interessar em trabalhar na nossa comunidade e esperamos que elas sejam respeitadas por todos, o que inclui, evidentemente, os moradores da comunidade de Galiléia.

Atenciosamente,

Sebastião, Gladistone, Luciana, Esmelinda, Simião, Silvana, Teresinha, Lúcia, Cristina, Walquer, Alessandro e Aparecida (representantes da comunidade de Galiléia).

\section{Considerações Finais}

A proposta central desse artigo foi apresentar os resultados da metodologia elaborada para o trabalho de iniciação ao pensamento sobre o turismo de base comunitária na comunidade de Galiléia, Município de Caparaó, Minas Gerais. Através do uso de métodos de três tipos de metodologias participativas, buscou-se uma forma de estimular a participação e o poder de decisão desses atores em relação à possível implantação do turismo na comunidade.

Foram várias as contribuições que as metodologias participativas puderam oferecer ao planejamento do turismo de base comunitária. A maior delas foi, certamente, a de estimular nos autóctones a reivindicação de seus direitos na participação dos benefícios da atividade turística através da problematização do turismo em relação à realidade de vida local. Além disso, por meio do uso de diferentes métodos a fim de aumentar a participação da população local na construção de conhecimentos diversos, foi possível disseminar entre os atores locais o entendimento dos possíveis impactos do turismo em uma localidade, para que tivessem uma percepção crítica acerca da atividade turística e, dessa forma, pudessem realmente defender seus interesses na implantação do turismo em seu território.

Nesse sentido, aplicando esses métodos no trabalho de planejamento turístico de base comunitária na comunidade de Galiléia, observou-se que sua utilização em localidades onde o 
turismo ainda não é uma realidade, é tão viável quanto necessária. Através de seu uso foi possível dar voz aos atores locais (o que geralmente não acontece nos planos turísticos convencionais) e, através das experiências e reflexões que eles proporcionaram, verificar a existência e consolidar uma visão crítica dos mesmos em relação ao modelo tradicional de turismo.

Dessa forma, os métodos e filosofias das metodologias participativas utilizadas contribuíram para que a realidade do turismo em outras localidades, como Caparaó e Alto Caparaó-MG, fossem espontaneamente problematizadas em relação ao modo de vida na Galiléia e, assim, permitiram a criação de um pensamento favorável à proposta de implantação do turismo de base comunitária na comunidade. Portanto, é possível afirmar que o uso dessas metodologias pode contribuir para se pensar intervenções mais críticas em relação ao turismo em um determinado território, do qual a realidade do turismo já faz parte de seu cotidiano. Pode-se afirmar, ainda, que a sua aplicação em um processo inicial de planejamento turístico comunitário, em lugares onde o turismo ainda não se configurou como uma realidade local, pode contribuir para a afirmação da identidade cultural local, o empoderamento da população e a autogestão de seu patrimônio comunitário, aspectos que preparam o terreno para a consolidação de uma proposta de turismo que seja mais condizente com a realidade de vida local.

A partir do trabalho de iniciação ao planejamento do turismo de base comunitária na comunidade de Galiléia observou-se que o conhecimento dos impactos positivos e negativos do turismo não é uma exclusividade das populações que têm o turismo como uma realidade cotidiana. Ao contrário, os atores locais que vivem no entorno das localidades turísticas também conhecem bem as implicações e benefícios dessa atividade, o que contribui para que tenham um posicionamento crítico em relação à sua implantação em seu território e, dessa forma, estabeleçam diversas condições para que o turismo possa se configurar como uma atividade econômica, cultural e social local. Ao mesmo tempo, esse trabalho na comunidade contribuiu para o reconhecimento do território e identidade cultural local, enquanto constituintes do seu patrimônio comunitário, cuja gestão ao longo do tempo depende do nível de articulação e união desses atores locais. 
Enfim, pôde-se constatar que os anseios e desejos da população da Galiléia em relação à implantação do turismo na comunidade correspondeu, em diversos aspectos, à proposta de turismo de base comunitária, o que reforçou a idéia de que essa nova proposta de planejamento e gestão turísticos é uma alternativa viável e, ao mesmo tempo, necessária às comunidades tradicionais como a Galiléia. Além disso, garantiu-se que, nos moldes do turismo comunitário, a população poderia trabalhar o tipo de turismo que desejasse em sua comunidade, colocando suas condições e restrições ao seu desenvolvimento, ou seja, fazendo valer o seu poder de decisão em relação ao mesmo.

Acredita-se, portanto, que a comunidade de Galiléia, com o intermédio da pesquisadora, deu seu primeiro passo para o planejamento do turismo de base comunitária em seu território e, através da "Carta da Galiléia para o turismo" e da sua articulação em torno de seus interesses comuns, tem condições de dar continuidade a esse trabalho, caso deseje trabalhar o turismo como uma atividade complementar em seu território e tenha a ajuda de uma equipe de profissionais de turismo para tanto.

\section{Referências}

ABRALUZ - Associação Brasileira dos Amigos do Caminho da Luz. Disponível em: http://www.caminhodaluz.org.br/index.php?option=com_content\&view=article\&id=68\&Itemid=91. Acesso em: 08 mar, 2011.

BOTELHO, Eloíse Silveira. Considerações sobre turismo, comunidade e educação ambiental: o caso de Ibitipoca. Rio de Janeiro: Caderno virtual de turismo. v.6, n.3, 2006. p.10-19. Disponível em: http://www.ivt.coppe.ufrj.br/caderno/ojs/viewarticle.php?id=129. Acesso em: 02 ago, 2007.

CHIZZOTTI, Antônio. Pesquisa em ciências humanas e sociais. São Paulo: Cortez, 2001.

DIAS, Reinaldo. Planejamento do turismo: política e desenvolvimento do turismo no Brasil. São Paulo: Atlas, 2003, 226p.

DIESEL, V.; SILVEIRA, P. R. C. ; ANDRES, M. ; BALEM, T. Desenvolvimento Territorial e Metodologias Participativas: encontros e desencontros. XLII Congresso Brasileiro de Economia e Sociologia Rural. Cuiabá, 2004. v. único. p. 01-20.

FERNANDES, Lindomar. Turismo comunitário: uma proposta em construção - O caso do Brasil. In: NEUHAUS, Esther.; SILVA, Jefferson Souza da. (orgs.). Um outro turismo é possivel! Reflexões sobre desigualdades, resistências e alternativas no desenvolvimento turístico. Fortaleza-CE, 2006. p.53-57. Disponível em: http://www.sits2008.org.br/oktiva.net/1893/secao/16333. Acesso em: 20 mai, 2008 . 
FURTADO, Ribamar.; FURTADO, Eliane. A intervenção participativa dos atores-INPA: uma metodologia de capacitação para o desenvolvimento local sustentável. Brasília: Instituto Interamericano de cooperação para a agricultura (IICA), 2000.

Grupo de Intervenções em turismo no V Fórum Social Mundial. Declaração de Porto Alegre, 2005 Um outro turismo é possível. In: NEUHAUS, Esther.; SILVA, Jefferson Souza da. (orgs.). Um outro turismo é possivel! Reflexões sobre desigualdades, resistências e alternativas no desenvolvimento turístico. $\quad$ Fortaleza-CE, 2006. p.73-75. Disponível em: http://www.sits2008.org.br/oktiva.net/1893/secao/16333. Acesso em: 20 mai, 2008.

IBAMA- Instituto Brasileiro do Meio Ambiente e dos Recursos Naturais Renováveis. Unidade: Parque Nacional do Caparaó. Disponível em: http://www.ibama.gov.br. Acesso em: 02 ago, 2007.

MENDONÇA, Teresa Cristina de. Turismo e participação comunitária: Prainha do Canto Verde, a "canoa" que não quebrou e a "fonte" que não secou? 2004. 209f. Dissertação (Mestrado em Psicossociologia de Comunidade e Ecologia Social) - Centro de Filosofia e Ciências Humanas, Universidade Federal do Rio de Janeiro, Rio de Janeiro. Disponível em: http://www.sits2008.org.br/oktiva.net/1893/secao/16333. Acesso em: 20 mai, 2008.

MITRAUD, S. Manual de Ecoturismo de base comunitária: ferramentas para um planejamento sustentável. Brasília: WWF-Brasil, 2003. 470p.

MURTA, Stela Maris. Turismo, preservação e comunidade. Belo Horizonte: $4^{\circ}$ congresso anual de ecoturismo, 2000.

OLIVEIRA, Alexandra Campos. A atividade turística e seus efeitos à população local: um paradoxo. Caderno virtual de turismo, v.5, n.2, 2005. Artigo disponível em http://www.ivt.coppe.ufrj.br/caderno/ojs/viewarticle.php?id=91. Acesso em: 02 ago, 2007.

PRADO, Francisco de Borja López de.; NUNES, Gilson Antônio. Projeto Praça da Astronomia de Caparaó: aparelhos, modelos e atividades cultural-educativas. Universidade Federal de Minas Gerais; Colégio Técnico da UFMG-COLTEC. Projeto Educação Ambiental em Caparaó: proposta de construção de uma comunidade de aprendizagem. Abril de 2003.

Projeto Doces Matas-MG. O trabalho em comunidades rurais no entorno de Unidades de Conservação. Fundação Biodiversitas-IEF-IBAMA-GTZ. Belo Horizonte, dezembro de 2001.

RAMOS, Silvana Pirillo. Observatório do Turismo: Núcleo de Avaliação, Diagnóstico e Intervenção no Desenvolvimento Sustentável do Turismo em Municípios do Estado de Alagoas. São Paulo: Instituto Ethos, $1997 . \quad$ Disponível em: http://www.ethos.org.br/_Uniethos/Documents/Observat\%C3\%B3rio\%20do\%20Turismo.pdf. Acesso em: $20 \mathrm{fev}, 2008$.

RODRIGUES, Adyr Balastreri. Turismo e espaço: rumo a um conhecimento transdisciplinar. São Paulo: Hucitec, 1999.

SAMPAIO, C.; OYARZÚNH, E.; SOUZA, M.; CÁRCAMO, C.; MANTOVANELI JÚNIOR, O. Arranjo socioprodutivo de base comunitária: análise comparativa de experiências de turismo comunitário no Brasil e no Chile. IV Seminário de pesquisa em turismo do mercosul. Caxias do Sul. 7
a
8
de julho
de
2006.
Disponível
em: 
www.ucs.br/.../posgraduacao/strictosensu/turismo/seminarios/seminario_4/arquivos_4_seminario/GT1 1-A8.pdf. Acesso em: 16 mai, 2008.

SANT'ANNA, Dalva Maria.; OLIVEIRA, Maria Teresa Chenaud Sá de.; BERESTEIN, Symara Gropper. Gestão participativa para um turismo sustentável: o caso da Costa do Descobrimento. Salvador: Bahia Análise e Dados. SEI, v.11, n.2, p.125-130, setembro 2001.

TURISOL. Rede brasileira de Turismo Solidário e Comunitário. Apresentação da rede, 2008. 30p. Disponível em: http://turisol.files.wordpress.com/2008/07/proposta.pdf. Acesso em 04 jun, 2008.

VERDEJO, M. E. Diagnóstico Rural Participativo - guia prático. Brasília, Secretaria da Agricultura Familiar, Ministério do Desenvolvimento Agrário, 2006.

WEBER, M. Economia e sociedade: fundamentos da sociologia compreensiva. Brasília: UNB, 1994.

Recebido em: 15/12/2009 (1 ${ }^{\mathrm{a}}$ versão) $15 / 03 / 2011$ ( $2^{\mathrm{a}}$ versão)

Aprovado em: 25/04/2011 


\begin{abstract}
ANEXOS
Anexo 01 - Descrição da ferramenta Mapa da Comunidade (VERDEJO, 2006. p.26)

Objetivo: visualizar a estrutura social da comunidade, número de lares e o tipo de ocupação do espaço da mesma.

Materiais: papéis e lápis.

Procedimentos: pedir que se represente o espaço da comunidade com os elementos de referência (escola, igreja, rios e córregos, estradas) e, a partir deles, a localização das casas dos habitantes da mesma. Como se trata de uma representação da realidade atual da comunidade, pode-se estimular os atores a falarem como era a ocupação desse espaço no passado, sobre a localização das áreas de mata e de lavoura, dentre outros aspectos da história local.
\end{abstract}

\title{
Anexo 02 - Descrição da ferramenta Árvore Genealógica
}

Objetivo: visualizar a união dos atores locais por laços familiares.

Materiais: papéis e lápis.

Procedimentos: pedir que, ao longo da construção da árvore genealógica das famílias fundadoras da comunidade, se identifiquem as famílias que permaneceram na mesma.

\section{Anexo 03 - Descrição da ferramenta Calendário Agrícola (VERDEJO, 2006. p.31)}

Objetivo: identificar produtos que são cultivados na comunidade e em que épocas são realizados. Visualizar as épocas de muito trabalho, as principais atividades cotidianas dos atores e os ciclos agrícolas.

Materiais: papéis e lápis.

Procedimentos: iniciar a construção do calendário definindo a escala do tempo (semanas, meses, estações, etc.). Constrói-se uma tabela na qual serão inseridas as informações sobre o cultivo mais importante na comunidade e demais culturas, seguindo-se uma escala do mais importante para o de menor importância. 